\title{
7 Non-Domination and Political Liberal Citizenship Education
}

\author{
Blain Neufeld
}

\section{Introduction}

According to Philip Pettit, we should endorse "republican" liberty, freedom as "non-domination," as a "supreme political value," that is, "a value with a distinctive claim to the role of yardstick for our institutions" (Pettit 1997,80$).{ }^{1}$ It is this commitment to freedom as non-domination that distinguishes republicanism from various forms of liberal egalitarianism, including the political liberalism of John Rawls (Rawls 2001, 2005). Some political liberals challenge this claim. They hold that the main elements of political liberalism can be construed as comprising a robust commitment to non-domination for all citizens. According to Anthony Laden, for instance, "there is a rather close correlation between [... .] the distinctive features of republicanism and those of political liberalism" (Laden 2006, 342). More strongly, Andrés De Francisco contends that appreciation of the core elements of political liberalism, and especially its ideal of free and equal citizenship, show that "Rawls is as republican as one can be" (De Francisco 2006, 287).

So is republicanism an alternative to political liberalism? Or does political liberalism (at least implicitly) include, or perhaps even rest upon, a commitment to non-domination?

In order to answer these questions, we need to distinguish between a "political" conception of non-domination and a "comprehensive" conception. If we construe republican liberty as a comprehensive moral ideal, or as necessarily embedded within a particular comprehensive moral doctrine,$^{2}$ then it seems clear that republicanism is distinct from political liberalism. But if we construe non-domination as a distinctly political ideal, then political liberalism is thoroughly republican in nature.

In this paper I will outline a political conception of non-domination and propose that it is an integral part of political liberalism. The latter claim will be defended via an exploration of the kind of "citizenship education" 3 that political liberalism mandates for all students. Such an education would impart to future citizens the skills and knowledge necessary for them to realize republican freedom vis-à-vis their political 


\section{Blain Neufeld}

institutions and workplaces. The limited scope of the political conception of non-domination, though, gives rise to the worry that it ignores relations of domination in certain kinds of associations, such as those within traditional religious communities. I address this worry by explaining that a political liberal citizenship education requires that all students learn that they have, among their rights of citizenship, an enforceable "right of exit" with respect to all associations in society, including religious communities, and, moreover, that students learn how to exercise this right.

\section{Political Liberalism, Civic Respect, and the Political Conception of Persons}

Citizens living in liberal societies, according to Rawls, invariably will subscribe to a variety of different, typically incompatible, philosophical, moral, and religious "comprehensive doctrines." ("Comprehensive doctrines" are philosophical, moral, and religious views-such as Buddhism and utilitarianism-that apply to most or all aspects of persons' lives.) Rawls calls this the "fact of reasonable pluralism" (Rawls 2005, $441,445)$. This pluralism would exist even in a fully just liberal society, and can be eliminated only through the exercise of political oppression (Rawls 2005, 37).

In order to accommodate the fact of reasonable pluralism, Rawls holds that the main political and economic institutions of a liberal society should be governed by a "political conception of justice." A political conception of justice satisfies what may be called the "basic structure restriction" and the "freestanding condition." According to the basic structure restriction, a political conception of justice applies only to the basic structure of society-its main political and economic institutions, taken together as an overall system-and not to social, philosophical, or moral concerns that lie beyond this domain. ${ }^{4}$ A political conception of justice satisfies the freestanding condition by being formulated in terms of "purely political" ideas (concepts, principles, ideals, and values). Such political ideas do not presuppose the truth of any particular comprehensive doctrine. Instead, they are compatible with, and ideally embedded within, ${ }^{5}$ the different comprehensive doctrines endorsed by that society's citizens (Rawls 2005, 11-16, 374-76). ${ }^{6}$

One normative political idea of central importance within political liberalism is that of citizens as "reasonable" and "rational" persons. Reasonable persons, roughly, acknowledge the fact of reasonable pluralism, and share a commitment to satisfying what Rawls calls the "criterion of reciprocity" when justifying fundamental political decisions to one another (Rawls 2005, xliv, 16, 49-50, 54). The criterion of reciprocity is the "intrinsic (moral) political ideal" of political liberalism (Rawls 2005, xlv). In order to satisfy this criterion in their political relations with each other, citizens must justify their political proposals in terms that they 


\section{뭉}

Non-Domination and Citizenship Education

think that other citizens (at least those similarly committed to the criterion of reciprocity) can accept. The reasonableness of persons expresses itself in what Rawls calls the first "moral power" of citizens, namely, their capacity for a "sense of justice." "

One way to understand how citizens can be reasonable persons and exercise effectively their sense of justice in their relations with one another is to see reasonableness as a form of mutual respect. Given its political nature, I refer to this conception of mutual respect as "civic respect." Civic respect has four features: ${ }^{8}$

1. It is a condition of civic respect that citizens acknowledge the fact of reasonable pluralism.

2. Civic respect is a form of what Stephen Darwall calls "recognition respect" (Darwall 1995, 2006). Recognition respect, roughly, is that respect which is owed to persons in virtue of some characteristic that they possess; this characteristic grants such persons a certain standing in their relations with others. ${ }^{9}$ Civic respect is a form of recognition respect that is owed to persons in virtue of their standing as free and equal citizens. One expresses such respect by taking this standing into account when deciding fundamental political questions in concert with one's fellow citizens. ${ }^{10}$

3. Because civic respect is owed to persons qua citizens, it is limited in scope to relations among citizens within the basic structure of society. ${ }^{11}$

4. The fourth feature of civic respect requires that citizens decide fundamental political questions-questions regarding "constitutional essentials" and "matters of basic justice" (Rawls 2005, 214-15, 227-30, 235) - in a way that satisfies the criterion of reciprocity, that is (given the first three features of civic respect), in accordance with the idea of "public reason."

"Public reason" is the name that Rawls gives to the shared form of reasoning that the citizens of a democratic society characterized by reasonable pluralism should use when deciding fundamental political questions (constitutional essentials and matters of basic justice). According to Rawls, public reason should be understood as "part of the idea of democracy itself" (Rawls 2005, 441). The terms of public reason are provided by the family of reasonable political conceptions of justice endorsed by citizens. ${ }^{12}$ Public reason, then, endeavors to operate independently of particular comprehensive doctrines. ${ }^{13}$ Political decisions concerning constitutional essentials and matters of basic justice made by means of public reason satisfy what Rawls calls the "liberal principle of legitimacy" (Rawls 2005, xliv, 137). Such decisions consequently have normative authority for citizens (Rawls 2005, 19). This is because the public reasons that justify those decisions are acceptable to all reasonable citizens, even though they adhere to different comprehensive doctrines. 


\section{Blain Neufeld}

In addition to being reasonable, Rawls's political conception of persons characterize them as "rational." Persons' rational nature includes what Rawls refers to as their second moral power, namely, their capacity to form, revise, and pursue conceptions of the good. A conception of the good "is an ordered family of final ends and aims which specifies a person's conception of what is of value in human life or, alternatively, of what is regarded as a fully worthwhile life" (Rawls 2001, 19). ${ }^{14}$ Rational persons, then, are (adequately) capable of determining what kinds of lives they judge to be of value for themselves, and pursuing or revising those determinations over the course of their lives.

According to political liberalism, the ability of persons to exercise effectively their two moral powers-their capacities for a sense of justice and a conception of the good-comprise their "higher-order interests" (Rawls 2005, 74-75, 106). And while persons are characterized as both reasonable and rational, their reasonable nature (their sense of justice) is understood to constrain their rational pursuit of their respective conceptions of the good. ${ }^{15}$ This conception of the person, Rawls stresses, "is meant as both normative and political, not metaphysical or psychological" (Rawls 2001, 19). The normative political conception of the person that is central to political liberalism does not rest upon any particular comprehensive doctrine, and thus is compatible with the fact of reasonable pluralism. This means that it is a conception that can be accepted by citizens irrespective of which comprehensive doctrines they endorse.

I propose that the political conception of the person help guide liberal citizenship education. More precisely, my recommendation is that the political conception of persons as reasonable and rational be used to help determine the requirements of citizenship education in contemporary liberal democratic societies characterized by reasonable pluralism. ${ }^{16} \mathrm{I}$ discuss these educational requirements in section 3. Before doing so, though, I will outline the main elements of the republican conception of freedom.

\section{Republican Freedom}

A person is free in the republican sense insofar as she is free from domination. An agent dominates or subjugates another agent insofar as the former enjoys the effective capacity to interfere "at will" with the decisions and actions of the latter. More precisely, one agent $(A)$ dominates another $(B)$ if the following three conditions are satisfied (Pettit 1997, 52):

1. $A$ has the power to interfere with $B$.

2. $A$ can interfere with $B$ on an arbitrary basis, that is, in a way that need not "track the interests" of $B$ (Pettit 1997, 272). ${ }^{17}$

3. $A$ can interfere with $B$ in certain choices that $B$ is in a position to make.

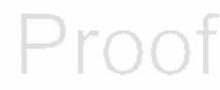




\section{:}

Importantly, the actual exercise of dominating power by one agent over another is not necessary for domination to exist. "To the extent that I have a power of interfering without cost in your choice," Pettit explains, "I count as dominating you" (Pettit 2011, 707).

The most extreme form of domination is the master-slave relationship. A master can interfere in any aspect of a slave's life, with impunity, and such interference need not consider, let alone track, the interests of the slave. Generally, though, capacities to interfere will vary in degree or intensity, as dominating power is rarely absolute. Moreover, dominating power often is restricted to only certain spheres of life-its scope typically is limited. For instance, in traditional patriarchal marriages, husbands dominate their wives, but this domination is not absolute, and does not extend beyond this relationship; such husbands may themselves be subject to domination by their employers in their workplaces.

A person enjoys republican freedom insofar as she is not subject to domination by other agents. Non-domination, according to Pettit, "involves the absence of domination in the presence of other people: it is a social ideal which requires that, though there are other people who might have been able to interfere with the person on an arbitrary basis, they are blocked from doing so" (Pettit 1997, 272). Agents are free in the republican sense, then, insofar as they possess and can exercise effectively institutional and social protections against arbitrary interference. ${ }^{18}$

Pettit holds that freedom as non-domination can be distinguished from the kind of freedom that Isaiah Berlin calls "negative freedom," that is, "freedom as non-interference" (see Berlin 1969a, 1969b; Pettit 2011). This is the kind of freedom that Pettit claims is endorsed by most liberal philosophers, including Rawls (Pettit 1997, 50, 111, 117; 2012, 10-11). According to this account, roughly, freedom consists in opportunities or pathways for action, whether those opportunities or pathways are taken or not. "The sense of freedom, in which I use this term," Berlin writes, "entails [...] the absence of obstacles to possible choices and activitiesabsence of obstructions on roads along which a man can decide to walk" (Berlin 1969a, xxxix-xl). Interference by other agents (whether individuals or collective agents, including the state) can limit one's negative liberty by closing such opportunities for action (say, through the imposition of obstacles or constraints), or by intentionally making them less viable by attaching costs or penalties to them (say, by issuing threats).

To see that "non-interfering domination" is possible, imagine a "benevolent dictator." This dictator does not interfere in most aspects of the lives of his subjects-that is, the dictator's subjects enjoy a high degree of negative freedom, perhaps even more than that enjoyed by the citizens of a democratic society with many laws and regulations. But the dictator, unlike the state within a liberal democratic society, enjoys the power to interfere arbitrarily, at will, with his subjects' lives. So while the dictator may refrain from interfering actively in most aspects of the lives of 
his subjects-the subjects may enjoy minimal interference in their daily lives-he nonetheless dominates them in virtue of his overwhelming capacity to interfere at will, in ways unconstrained or uncontrolled by his subjects' interests or powers.

One key difference between the conceptions of negative liberty and republican liberty concerns the question of whether all interferences are constraints on an agent's liberty. According to Berlin's account of negative liberty, all interferences constitute restrictions on liberty. ${ }^{19}$ Thus laws invariably restrict a person's liberty, as they prevent or impose costs (fines, imprisonment, and so forth) on certain courses of action, thereby limiting the range of options available to that person (or at least rendering costly some options). ${ }^{20}$ In contrast, republicans hold that not all interferences restrict liberty. "[I]nterference may occur without any domination," according to Pettit, because "if the interference is not arbitrary then it will not dominate" (Pettit 1997, 272).

Recall the second condition of domination mentioned earlier: $A$ dominates $B$ if $A$ can interfere with $B$ on an arbitrary basis. Insofar as the exercise of power by $A$ over $B$ is compelled to track the interests of $B$, that exercise is not arbitrary. Preventing the exercise of power by $A$ over $B$, or ensuring that that exercise tracks adequately $B$ 's interests, typically requires giving $B$ some way to check, influence, or control $A$ 's exercise of power. Thus $B$ 's republican liberty is not necessarily restricted by the exercise of power by $A$ over $B$-non-arbitrary interference is possible. Non-arbitrary interferences in agents' choices, such as those imposed by legitimate laws, are not restrictions on citizens' freedom, ${ }^{21}$ at least understood in the republican way.

\section{Political Liberal Citizenship Education and Republican Freedom}

Would a citizenship education based upon political liberalism foster in students the knowledge and skills necessary for them to be able to enjoy and exercise republican liberty? According to Pettit's understanding of Rawlsian political liberalism, there is no guarantee that this would be the case. This is because, as noted earlier, Pettit holds that Rawls employs Berlin's negative notion of liberty in his political writings. This claim, though, is not correct. The concept of liberty that Rawls in fact employs is that of the "triadic relation" formulated by Gerald G. MacCallum (1967). According to this concept, Rawls notes, "any liberty can be explained by a reference to three items: the agents who are free, the restrictions or limitations which they are free from, and what it is that they are free to do or not to do" (Rawls 1999, 177).22 Different "conceptions" of liberty specify the three items that comprise the "concept" of liberty in different ways. ${ }^{23}$ Applying this concept of liberty to political liberalism, the agents in question are citizens, understood as reasonable 
and rational persons, and what it is that they are free to do-or should be free to do-is to exercise their two moral powers, their capacities for an effective sense of justice and a conception of the good. The restrictions or limitations from which citizens should be free are interferences or constraints on citizens' exercise of those powers. ${ }^{24}$ So a political liberal citizenship education would teach students the skills, concepts, and virtues necessary for them to become capable of exercising effectively the two moral powers upon reaching adulthood, that is, to become reasonable and rational persons.

Teaching students how to become reasonable persons would require teaching them to understand and appreciate the fact of reasonable pluralism and the criterion of reciprocity-and, consequently, to employ the terms of public reason when helping to decide fundamental political questions. In other words, a political liberal citizenship education would teach students the skills and concepts necessary for them to be able to interact with others on the basis of civic respect. ${ }^{25}$ And teaching students how to be rational persons would involve (inter alia) ensuring that they are aware of the diverse range of conceptions of the good and comprehensive doctrines that exist in their society, that they know how to exercise their rights and liberties, especially with respect to forming, revising, and pursuing their conceptions of the good, and that they possess sufficient knowledge and skills to be economically independent as adults, so that they need not be dependent on others in order to pursue their conceptions of the good.

Would a political liberal citizenship education with these goals promote a capacity for republican freedom in future citizens? If we construe republican freedom as a political ideal, then a political liberal citizenship education unavoidably would aim at realizing republican freedom for all citizens.

To understand the distinction between a political conception of nondomination and a comprehensive conception, consider first Rawls's distinction between "political" autonomy and "comprehensive" or "ethical" autonomy. Rawls claims that political autonomy and ethical autonomy are philosophically distinct ideas. According to political liberalism, citizens must enjoy "full political autonomy." This form of autonomy, Rawls explains, is "the legal independence and assured political integrity of citizens and their sharing with other citizens equally in the exercise of political power" (Rawls 2005, xliv) ${ }^{26}$ Understood in this way, political autonomy can be distinguished from an ethical or comprehensive conception of autonomy that applies to the whole of life, both social and individual. So while political liberalism "affirms political autonomy for all," Rawls claims that it "leaves the weight of ethical autonomy to be decided by citizens severally in light of their comprehensive doctrines" (Rawls 2005, 78). Political autonomy can be distinguished from ethical autonomy by 


\section{Blain Neufeld}

its compliance with political liberalism's freestanding condition and basic structure restriction.

The distinction between political and ethical autonomy has educational implications. In Political Liberalism, Rawls briefly considers the scope of the "requirements the state can impose" on the education of children belonging to "religious sects [that] oppose the culture of the modern world and wish to lead their common life apart from its unwanted influences." "Comprehensive" liberal approaches to education, he explains, "may lead to requirements designed to foster the values of autonomy and individuality." By contrast, "political liberalism has a different aim and requires far less" (Rawls 2005, 1999). A political liberal citizenship education aims at ensuring that all future citizens can enjoy and exercise political autonomy. ${ }^{27}$

A similar distinction can be made between a political conception of non-domination and a comprehensive conception. The political conception of republican liberty satisfies the freestanding condition, as it can be understood as part of the political conception of the person, and thus compatible with the different reasonable comprehensive doctrines endorsed by citizens. ${ }^{28}$ And the political conception of republican freedom is limited in its scope to citizens' relations within the basic structure of society. A comprehensive conception of non-domination, in contrast, is based upon a particular comprehensive doctrine and/or applies to all domains of persons' lives. ${ }^{29}$

A political liberal citizenship education would promote a capacity to enjoy and exercise the political conception of republican freedom within future citizens in three main ways. ${ }^{30}$

First, as already noted, a political liberal citizenship education would teach students how to be politically autonomous. ${ }^{31}$ One aspect of such an education would involve teaching students about their political rights and liberties, including how to exercise them effectively once they become full citizens. $^{32}$ Such knowledge would promote relations of non-domination vis-à-vis the state and its various institutions and agents. In particular, a political liberal citizenship education would aim at ensuring that students know not only how to exercise their rights as citizens, but specifically how to do so in order to challenge the exercise of power by political institutions and agents. This means that students would be taught how the legal system of their society works, including its political system, what criteria political decisions and actions must satisfy in order for them to be legitimate and fair, what resources are available to citizens to challenge political decisions, and so forth. ${ }^{33}$

Another aspect of a political liberal citizenship education for political autonomy involves cultivating in students a capacity and a willingness to interact with other citizens on the basis of civic respect. ${ }^{34}$ Specifically, students would be taught how to employ the terms of public reason when deciding fundamental political questions, as well as how to challenge 
political decisions that are not made in terms of public reason. The idea of public reason supports the ideal of non-domination by requiring that fundamental political decisions be made on the basis of reasons acceptable to all reasonable persons. Hence such decisions must "track" adequately the interests of all persons affected by them. The requirements of public reason help secure political non-domination.

One pedagogic strategy for teaching students how to interact with others on the basis of civic respect involves requiring them to participate in class debates concerning a range of politically fundamental but divisive issues. ${ }^{35}$ These issues could be both historical, concerning pivotal issues in the political history of their society, and contemporary in nature. With respect to the latter, students might debate the political justifications in support of and against, say, the right to abortion, the legal recognition of same-sex marriages, the provision of a basic income for all citizens, the financing of political campaigns, the right to voluntary euthanasia, the right of citizens to wear religious clothing or symbols as public officers or during public ceremonies, and so forth.

After explaining to students that they live in a society characterized by persistent disagreement over a wide range of religious and moral questions-that is, a society characterized by reasonable pluralism-the rules of the debate would be introduced. The key rule would be that students formulate any argument concerning a fundamental political issue in a manner that respects the limits of public reason by not relying on any particular comprehensive doctrine. Arguments that violate the limits of public reason, by violating either the freestanding condition or the basic structure restriction, would be ruled inadmissible. Indeed, students would be encouraged to rise on "points of order" in order to help them identify such arguments, and learn to explain to others why they are inadmissible. Through participation in such debates, students would learn how to employ public reason justifications when deciding fundamental political questions. ${ }^{36}$

A political liberal citizenship education with such pedagogic exercises would help encourage students to regard and interact with their political system as a kind of "contestatory democracy." A contestatory democracy, according to Pettit, should be understood as based "on the contestability by the people of everything that government does." "[T]he important thing," he maintains, "to ensure is that governmental doings are fit to survive popular contestation" (Pettit 1997, 277). ${ }^{37}$ Moreover, a contestatory democracy is a political order that is (inter alia) deliberative and inclusive in nature. It is deliberative in that political decisions should be based upon considerations of common concern, which provide the grounds for citizens' challenges to government decisions and actions, and it is inclusive in that all citizens have adequate opportunities and resources to make such challenges (see Pettit 1997, ch. 6). The pedagogic strategy of employing practice political debates in citizenship classes is 


\section{Blain Neufeld}

supportive of this ideal. This is because such exercises would foster in students a capacity to evaluate critically, and if necessary debate and challenge, political decisions. Moreover, practice political debates and similar activities might help foster over time a general public political culture that is both deliberative and inclusive in nature. ${ }^{38}$

A second element of a political liberal citizenship education that would foster within students a capacity for republican freedom concerns the economic domain of society, and specifically relations amongst citizens within workplaces. All students, according to Rawls, should be taught the skills and knowledge necessary for them to become "economically independent and self-supporting members of society over a complete life" (Rawls 2005, 200). Such an education would involve preparing students for a range of occupations or kinds of employment upon reaching adulthood, ensure that they can compete fairly for positions and offices of authority, and so forth. The skills and knowledge imparted by a political liberal citizenship education would help ensure that future citizens are not dependent upon any particular employer or form of employment. The capacity of future employers to exercise domination over their employees thereby would be reduced (or, ideally, eliminated). ${ }^{39}$

Moreover, a political liberal citizenship education would ensure that all future citizens acquire knowledge of their economic rights, including knowledge of how to exercise effectively those rights. Students would be taught about their rights to personal property and to freedom of contract, as well as the limits of those rights. They also would be taught how to compete for positions and offices of authority and responsibility within both the public and private sectors of society. Part of learning about the latter right includes acquiring the knowledge necessary to challenge unjust hiring decisions. Students also would learn how to avail themselves of the basic resources and opportunities to which they are entitled as free and equal citizens (according to any reasonable conception of justice).$^{40}$ In short, a political liberal citizenship education would ensure that citizens are capable of enjoying and exercising republican freedom in the economic domain of their lives.

A third element of a political liberal citizenship education that would promote a capacity for republican liberty within future citizens concerns citizens' rights with respect to associations and relationships. A political liberal citizenship education would teach students how to assert and exercise their rights and liberties, upon reaching adulthood, in their relations with other citizens, as well as vis-à-vis the various non-state institutions and associations to which they belong, or with which they interact in some significant way, such as households, firms, clubs, and religious organizations. Such an education would provide future citizens with sufficient knowledge of how to call upon the institutions of the state in order to enforce their rights-especially those rights that protect citizens' freedom of association, conscience, movement, and occupation-against 
attempts by others to exercise arbitrary power over them. Of central importance here is citizens' "right of exit" with respect to any association or relationship (that is not part of the basic structure). ${ }^{41}$ This kind of knowledge is necessary for citizens to be able to exercise effectively their two moral powers, and especially their capacity to form, revise, and pursue their conceptions of the good. This knowledge also provides citizens with a resource by means of which they can avoid being subject to the dominating power of non-state agents, including other citizens. ${ }^{42}$

Finally, I should note that I have summarized here only the requirements of a political liberal citizenship education. Nothing within this account prohibits classes and other educational activities that, for instance, encourage students to explore critically different comprehensive doctrines, including religious views, or that assist students in acquiring and exercising a form of ethical autonomy. Such courses and activities, though, must be optional, as requiring them of all students would fail to accommodate the fact of reasonable pluralism.

\section{The Limits of Political Liberalism vis-à-vis Non-Domination}

In this section, I consider a limit on the potential of a political liberal citizenship education to promote republican freedom within future citizens. Recall that a political conception of justice applies only to the basic structure of society. This feature of political liberalism limits what the state can do with respect to relations of domination in those associations that are not part of the basic structure, such as traditional religious communities. Many religious communities assign different roles to men and women, and confer upon the roles occupied by men greater authority and power than those occupied by women. The asymmetrical gender relations within traditional patriarchal religious communities, then, may be relations of domination, and hence republican un-freedom. Children raised in such communities, moreover, may come to internalize these views and practices, believing that relations of domination based upon gender are justified, and subsequently reproduce such relations as adults (see Okin 2002). ${ }^{43}$

How significantly does the basic structure restriction of political liberalism limit the realization of republican liberty? Alternatively, to what extent (if any) can domination within associations coexist with the realization of the political conception of republican liberty for all citizens? There are two considerations that should inform our assessment of the extent to which political liberalism permits the existence of relations of domination within associations outside of the basic structure.

First, it is important to stress that all associations within society, including religious institutions and communities, must comply with the requirements of the basic structure. No association can violate the rights 


\section{Blain Neufeld}

and liberties of citizens. So the basic structure imposes constraints on all associations and practices within society. "Firms and labour unions, churches, universities, and the family are bound by constraints arising from the principles of justice," Rawls writes, "but these constraints arise indirectly from the just background institutions within which associations and groups exist, and by which the conduct of their members is restricted" (Rawls 2001, 10). Religious associations, then, cannot undermine the free and equal status of their members qua citizens, say, by prohibiting women from voting or running for political office, or by treating heresy and apostasy as punishable crimes. ${ }^{44}$ These are legitimate, coercively enforced, constraints on religious associations. Likewise, religious associations must respect their members' right of exit.

Second, recall that the requirements of citizenship education apply to all members of society (see Rawls 2005, 199). ${ }^{45}$ Fulfilling this educational goal requires public action. Ensuring that future citizens are free and equal is one that the state, representing the political community as a whole, must secure by legally coercive means if necessary. Roughly, the state ought to require by law that parents enroll their children in educational institutions that will prepare them to be free citizens, persons capable of exercising effectively the two moral powers upon reaching adulthood. ${ }^{46}$

Two features of such an education should be noted with respect to the cultivation of a capacity for republican freedom in students. First, the kind of citizenship education that political liberalism would mandate for all students would teach them to distinguish between those institutions that are components of their society's basic structure and those institutions and associations that are not parts of the basic structure. The latter includes, of course, the religious organizations and cultural communities to which students might belong. Second, with respect to those institutions, associations, and communities that are not constituents of the basic structure, students would be taught about their rights, including their right of exit, so that they will be capable of exercising this right effectively upon reaching adulthood. ${ }^{47}$ Moreover, students will be taught that the right of exit is enforceable (that as citizens they can call upon the power of the state to stop, coercively if necessary, any attempt by any individual or association to interfere with their exercise of this right). Students, in addition, would be taught that the right of exit applies to households. ${ }^{48}$ Knowledge of their society's divorce laws-as well as those institutions, laws, and policies that aim to promote and protect gender equality amongst citizens-would help reduce significantly the potential for one spouse to exercise dominating power over the other. ${ }^{49}$

What exactly teaching students about their right of exit with respect to the associations that are not part of the basic structure would involve is a difficult question that I cannot answer here. Any answer, though, would depend upon the society in question. My claim simply is that an adequate 
political liberal citizenship education would ensure that all future citizens, irrespective of gender or religious affiliation, know how to exercise effectively their right of exit vis-à-vis any association that is not part of the basic structure. An effective and enforceable right of exit would constrain significantly the ability of associations, such as religious institutions and communities, to exercise dominating power vis-à-vis their members.

With respect to citizenship education, however, it must be acknowledged that a political liberal approach can go only so far in promoting republican freedom in the lives of students. While a political liberal citizenship education would require that all students acquire the knowledge and skills necessary for them to be able to exercise effectively their right of exit as adults with respect to any association to which they belong, including hierarchical religious ones, it cannot legitimately aim at the elimination of hierarchical relations within such associations. In contrast, a citizenship education committed to promoting a comprehensive conception of republican freedom would not necessarily regard the promotion of such freedom within all aspects of students' lives to be morally problematic; indeed, such promotion may be a central pedagogic goal of a comprehensive republican citizenship education. ${ }^{50}$

Yet imposing a citizenship education that aims at promoting comprehensive republican liberty would itself, I think, be a form of domination. This is because such promotion would involve the exercise of state power in the service of a partisan moral ideal, a moral ideal not shared by all reasonable citizens. In other words, state promotion of republican liberty in all aspects of students' lives involves the exercise of political power in order to reduce the scope of reasonable pluralism (the range of comprehensive doctrines and associated conceptions of the good that citizens can adopt and pursue within their lives). Perhaps tragically, then, a citizenship education that aims at promoting within students a capacity to enjoy and exercise either political or comprehensive republican liberty cannot avoid permitting or employing some measure of dominating power in society. ${ }^{51}$

\section{Conclusion}

In this chapter I tried to show that a distinctly political conception of non-domination is an integral part of political liberalism. My discussion proceeded through consideration of the kind of citizenship education that political liberalism mandates for all students. Such an education would impart to future citizens the skills and knowledge necessary for them to realize republican freedom vis-à-vis their political institutions, their workplaces, and, by means of an enforceable right of exit, the various associations to which they might belong (including religious communities). Whether one prefers the political conception of non-domination that I defend here or a comprehensive version likely reflects whether one 


\section{Blain Neufeld}

is committed to accommodating the reasonable pluralism characteristic of contemporary societies. However, to choose not to accommodate this pluralism, I think, itself expresses a "dominating" stance with respect to many reasonable citizens' comprehensive doctrines. ${ }^{52}$

\section{Notes}

1 I focus on Pettit's conception of republican freedom in this chapter (Pettit 1996, 1997, 2011, 2012). For an overview of contemporary republican views, see Lovett 2014. (I use "non-domination," "republican liberty," and "republican freedom" interchangeably in my discussion.)

2 Pettit's version of republicanism, for instance, can be read as presupposing a form of consequentialism and as applying to citizens' social relations in general. It is not entirely clear, though, that it is in fact properly understood as a comprehensive (or partially comprehensive) view. Nevertheless, it is not as unambiguously "political” in nature as Rawls's version of liberalism. My aim in section 3 is to outline an explicitly political (non-comprehensive) version of republican freedom. (My thanks to Lars Moen for bringing this ambiguity in Pettit's version of republicanism to my attention.)

3 I refer to "citizenship education" instead of "civic education" in this chapter. "Civic education" often is construed to refer narrowly to the teaching of how the political institutions of society work, as well as citizens' rights and duties with respect to those institutions. "Citizenship education," as I use the term here, includes not only civic education so understood, but also the teaching of the skills and knowledge necessary for students to participate as free and equal citizens in all aspects of their society's "basic structure" (see section 1), including its economic structure, as well as the various political virtues important for democratic citizenship.

4 I defend (a version of) the basic structure restriction in Neufeld and Van Schoelandt 2014.

5 Rawls suggests that a political conception of justice can be understood as a "module" that can be integrated into citizens' comprehensive doctrines (Rawls 2005, 12-13, 145). (Such integration may require modifications in citizens' comprehensive doctrines.)

6 A third feature of a political conception of justice (not relevant to my discussion here) is that its freestanding political ideas are "seen as implicit in the public political culture of a democratic society" (Rawls 2005, 13).

7 "The capacity for a sense of justice," Rawls explains, "is the capacity to understand, to apply, and to act from (and not merely in accordance with) the principles of political justice that specify the fair terms of social cooperation" (Rawls 2001, 18-19).

8 This account draws upon Neufeld 2005.

9 A different kind of respect, "appraisal respect," "consists in a positive appraisal of a person or his qualities [. . . A Appraisal respect is the positive appraisal itself" (Darwall 1995, 184). Appraisal respect can be distinguished from recognition respect in that we might think that equal recognition respect is owed to persons for whom we have little or considerable appraisal respect.

10 This is not to say that a form of mutual respect does not apply to noncitizens as well. At the very least, the basic human rights of all persons must be respected irrespective of citizenship, and respect for others' human rights involves a form of recognition respect. However, since citizens exercise political sovereignty over each other (see Rawls 2005, 136, 214, 445), a more

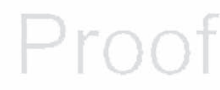


robust form of mutual recognition respect should govern their relations (or so I shall assume for the purposes of this chapter). (My thanks to Colin Macleod for pressing me to clarify this point.)

11 Civic respect, then, does not violate the basic structure restriction, and thus can be distinguished from other, more "comprehensive" forms of recognition respect, such as that required by Kant's "Formula of Humanity" (Kant 1998, 36-43). (Civic respect, of course, is compatible with comprehensive Kantian recognition respect.)

12 A "reasonable" conception of justice possesses three features (Rawls 2005, 450). First, it secures equally for all citizens a set of "basic liberties." (For the set of basic liberties secured by Rawls's conception of "justice as fairness," see Rawls 2001, 44, 2005, 291.) Second, it assigns to the basic liberties a "special priority" vis-à-vis other political principles and values (e.g., welfare). Third, it assures for all citizens adequate resources for them to exercise effectively their basic liberties over the course of their lives. A reasonable political conception of justice, then, is a conception that includes these three features, as well as satisfying the basic structure restriction and the freestanding condition. Rawls holds that his egalitarian conception of justice- "justice as fairness"-is "the most reasonable conception because it best satisfies these conditions" (Rawls 2005, xlvi).

13 When citizens decide fundamental political questions on the basis of public reason, they realize their "duty of civility" (Rawls 2005, 444).

14 Furthermore: "[t]he elements of such a conception are normally set within, and interpreted by, certain comprehensive religious, philosophical, or moral doctrines in light of which the various ends and aims are ordered and understood."

15 For more on the ideas of the reasonable and the rational, see: Rawls 2001, 6-7, 81-82, 191.

16 Rawls's political conception of the person underpins his conception of justice as fairness and his use of "ideal theory" in formulating and defending that conception. (On ideal theory, see: Rawls 1999, 7-8, 215-16, 308-09, 2001, $13,65-66,2005,285$. For an account of the relation between the ideas of public reason and ideal theory within political liberalism, see Neufeld 2017.) However, I think that the account of citizenship education that I outline here can be accepted irrespective of whether one endorses Rawls's specific conception of justice and/or his account of ideal theory. Even if readers reject ideal theory and/or justice as fairness, they nonetheless may find the political conception of the person to be an attractive ideal, an ecumenical yet compelling account of what it is to be a free citizen within a pluralist society, and thus one that should be part of citizenship education.

17 What constitutes "arbitrary" power of interference is a topic of debate amongst republican theorists (see Lovett 2014, section 2.2 for a helpful overview). I favor a "proceduralist" account according to which, roughly, nonarbitrary power is power that is constrained and regulated by publicly known rules and goals (Lovett 2012). In his recent work, Pettit has tried to dispense with references to "arbitrary power" altogether and instead focus on "uncontrolled" capacities for interference (Pettit 2012, 49-58). This approach, though, has been challenged as implausible (see Simpson 2017).

18 Moreover, like (most) relations of domination, relations of non-domination typically are common knowledge. Indeed, such common knowledge ensures (greater) equality of freedom among citizens. (Pettit 1997, 273.)

19 As we shall see in the next section, this is not the case with Rawls's account of liberty.

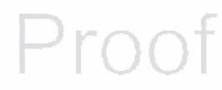




\section{Blain Neufeld}

20 Such limits on negative liberty may very well be justified, or even necessary to better secure persons' overall negative liberty (consider, for instance, laws against assault and murder). Berlin employs a "non-moralized" account of negative liberty. (A "moralized" account of liberty, roughly, would not categorize prohibitions on immoral or unjust actions as genuine constraints on persons' liberty.) In contrast, Pettit's conception of republican liberty, at least its earlier formulations (Pettit 1996, 1997), is a moralized conception (see List and Valentini 2016).

21 This is one of the more controversial aspects of Pettit's account of republican liberty. For criticism see: Ferejohn 2001; Talisse 2014; and List and Valentini 2016.

22 Rawls notes that he "follows" MacCallum in this respect (Rawls 1999, 177, n.4).

23 On the distinction between "concepts" and "conceptions," which Rawls claims to have derived from H.L.A. Hart, see Rawls 1999, 5.

24 "The basic liberties," Rawls explains, "are a framework of legally protected paths and opportunities" (Rawls 2005, 325). These "legally protected paths and opportunities" are those that enable citizens to exercise their sense of justice and their capacity to form, revise, and pursue conceptions of the good free from interferences from other agents, including collective agents such as firms, religious associations, and the state.

25 Most versions of comprehensive liberalism also are committed to teaching students how to interact with others on the basis of mutual respect (e.g., Gutmann 1995). However, the conception of civic respect that I have attributed to political liberalism differs from (most) comprehensive liberal conceptions of mutual respect in virtue of political liberalism's distinctive commitment to the freestanding condition and the basic structure restriction (see Davis and Neufeld 2007).

26 Elsewhere, Rawls writes that political autonomy "is realized in public life by affirming the political principles of justice and enjoying the protections of the basic rights and liberties; it is also realized by participating in society's public affairs and sharing in its collective self-determination over time" (Rawls $2005,77-78)$. The conception of civic respect outlined in section 1 helps explain how politically autonomous citizens can share in society's "collective self-determination over time," namely, by helping to decide fundamental political questions together on the basis of public reason.

27 This is not to deny that teaching students to become politically autonomous might lead some (or many) students to come to value and exercise ethical autonomy in the other aspects of their lives-a possibility that Rawls acknowledges (Rawls 2005, 199-200; for further discussion see Davis and Neufeld 2007).

28 It may seem that Rawls makes a similar point himself: "Since classical republicanism does not involve a comprehensive doctrine, it is [. . .] fully compatible with political liberalism" (Rawls 2001, 144). However, by "classical republicanism" Rawls does not refer to something like Pettit's notion of freedom as non-domination. Rather, Rawls has in mind citizens' exercise of political autonomy.

29 Whether Pettit's version of republicanism should be understood as a comprehensive or partially comprehensive view is unclear (see n. 2). My aim here is to make explicit what a political conception of republican freedom would look like.

30 Just as teaching students how to exercise political autonomy may lead some to endorse an ideal of ethical autonomy in areas of their lives beyond the basic 


\section{Proof}

Non-Domination and Citizenship Education

structure (see n. 27), so too teaching students the concepts and skills necessary for "political" non-domination may lead some to endorse a "comprehensive" version. Such "spillover effects" may be unavoidable, but they fail to remove the distinction - in both theory and practice- between the political and comprehensive conceptions of these ideas. (My thanks to Michael Barnes for discussion of this point.)

31 Laden points out that political liberalism's concern with securing the political autonomy of citizens prevents the exercise of arbitrary power by the state with respect to them (see Laden 2006, 354).

32 Rawls holds that, given society's concern with students' "role as future citizens," students must acquire "the capacity to understand the public culture and participate in its institutions" (Rawls 2005, 200).

33 Of course, the institutional resources available to citizens for challenging political decisions often are inadequate within existing liberal democratic societies. Such societies, after all, are not well-ordered societies (see n. 16). Nonetheless, a citizenship education that cultivates in students within nonideal circumstances the capacity to form and act upon a sense of justice would impart to them the skills and knowledge necessary to make use of what resources are available to them to challenge those political decisions with which they disagree, as well as to promote the policies and institutions that they think are required by justice. Such an education, then, likely would contribute to the improvement of the political and legal institutions of students' societies, as their capacity to act upon their sense of justice would enable them to help improve the justice of those institutions. This is one important way in which citizenship education can play a role with respect to transitional justice.

34 Such an education would be part of "developing the political virtues" within future citizens (Rawls 2005, 200).

35 This example is discussed in Davis and Neufeld 2007; and Neufeld 2013. It realizes (at least) two of the six pedagogic practices- "Deliberations of current, controversial issues," and "Simulations of adult civic roles"-identified by Levine and Kawashima-Ginsberg $(2017,4)$ as proven to be effective with respect to civic learning.

36 Some critics of the idea of public reason hold that it imposes unfair burdens upon citizens of faith (and in this context, students of faith). This is because such citizens often find it necessary to draw upon their religious views in order to decide certain fundamental political questions (for instance, whether abortion or physician-assisted suicide should be legally permitted), and find it difficult or even impossible to offer public reasons for their positions. Moreover, to the extent that religious citizens might try to provide public reasons, their "integrity" may be threatened, as the reasons that such citizens take to be the most important ones applicable to certain issues may conflict with the available public reasons concerning those issues. (E.g., see: Wolterstorff 1997; and Vallier 2012.) I cannot reply to this line of criticism here, except to note that I think that the kind of "compartmentalization" that the idea of public reason may require of some citizens with respect to their comprehensive views (including their religious beliefs) need not be "integrity-threatening" in nature (see Davis and Neufeld 2007, section 3). For a robust response to this line of criticism, in support of Rawlsian public reason, see Watson and Hartley 2018, ch. 4.

37 "The emerging conception of democracy insists that the point is to create a testing environment of selection for laws, rather than to have laws that are consensually designed" (Pettit 1997, 278).

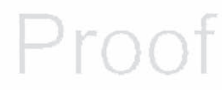




\section{Blain Neufeld}

38 Rawls describes the conception of political self-government based upon the idea of public reason as a form of "deliberative democracy" (Rawls 2005, 448-50). Does Pettit's contrast between a conception of democracy that is "contestatory" in nature and one that is "consensual" indicate an important difference with Rawls's deliberative conception of democracy? I do not think that it does. Shared acceptance of the terms of public reason does not require or presuppose that all reasonable citizens endorse the particular laws that are enacted by their political representatives (as Rawls remarks, "unanimity of views is not to be expected" [Rawls 2005, 479].) Pettit himself describes a Rawlsian well-ordered society as a "civicity": a form of social organization that is neither a unified corporate entity nor an aggregation of disparate individuals (Pettit 2006).

39 Of course, realizing non-domination within workplaces requires (much) more than education (see Anderson 2017).

40 These resources and opportunities are "all-purpose means" (including, inter alia, income and wealth) necessary for citizens to exercise effectively their two moral powers. Again, existing liberal democratic societies may secure inadequate resources for citizens in this respect, but a political liberal citizenship education that inculcates in students a capacity for an effective sense of justice would enable future citizens to act to make the basic structures of their societies more just, including the adequate provision of all-purpose means for citizens to exercise their basic liberties.

41 The right of exit is a core element of citizens' freedom of association, a freedom that must be realized institutionally within any minimally just liberal society.

42 While I focus on the right of exit in securing non-domination in this chapter, other rights, such as those protecting liberty of conscience and freedom of speech, also are important in promoting citizens' republican freedom. Such rights help ensure that citizens have a "voice" with respect to the associations to which they belong. Citizens within a liberal society, then, can try to counter or alter relations of domination within associations through criticism and debate. I focus on the right of exit here, though, as I take it to be the ultimate institutional protector of republican liberty in a pluralist liberal society. (My thanks to Lori Watson for discussion of this point.)

43 Hence Okin is critical of Rawlsian political liberalism for its refusal to condemn as "unreasonable" the gendered views and practices of many traditional religious communities (Okin 1994, 31f, 2005, 241-42).

44 For Rawls's use of these examples, see Rawls 2001, 11, 164.

45 Such an education may indirectly encourage the revision of elements of students' comprehensive doctrines so that they are compatible with or supportive of liberal rights and the idea of public reason (see n. 5). (Thanks to Lori Watson for this point.)

46 While the state ultimately would be responsible for ensuring that children received such an education, non-state institutions could be the relevant education providers, so long as they satisfied appropriate, legally enforced, educational requirements (see Davis and Neufeld 2007).

47 As noted earlier (n. 42), other rights also can help to combat domination within associations by giving citizens a "voice" with respect to internal life of those associations. The right of exit, though, serves as the ultimate institutional protector of republican freedom.

48 Rawls includes families within his account of the basic structure (Rawls 2005, 258). Yet in his discussions of how political principles of justice apply to families, he treats them in the same way as those "voluntary associations" that he explicitly identifies as not part of the basic structure (e.g., Rawls 2001, 


\section{:}

Non-Domination and Citizenship Education

10). I address this feature of Rawlsian political liberalism - and attempt to provide a solution, according to which (roughly) aspects of households are directly subject to principles of justice-in Neufeld 2009; and Neufeld and Van Schoelandt 2014.

49 Existing political societies generally do not secure (adequately) the free and equal status of women qua citizens within their basic structures. Rawls acknowledges that securing the freedom and equality of women qua citizens requires revising existing unjust laws, including divorce laws (Rawls 2001, 167). For further discussion of this issue, see Neufeld 2009; and Hartley and Watson 2010.

50 Of course, republicans can allow that there may be practical considerations, or other important values, that weigh against acting on such an educational aim in many circumstances.

51 A political liberal might claim here that if a person chooses to remain a member of a hierarchical association (roughly, that person knows how to exercise effectively the right of exit but chooses not to do so), then that association does not dominate that person. This is because that person's interests are being adequately "tracked" by remaining a member of the association in question (if this were not so, the person would have left the association). While this response is partially successful, I think, in reducing the practical differences between the political and comprehensive conceptions of nondomination, it leaves out the possibility that a person might remain a member of an association that subjects her to domination because of her other values and commitments (say, ties to families and communities, religious convictions, and so forth). While persons who remain members of such associations may use their rights to try to reform those associations, there obviously is no guarantee that such efforts will be successful. Such persons thus may choose to remain "unfree," in the republican sense, despite their right of exit. (My thanks to Elizabeth Edenberg and Andrew Franklin-Hall for helpful discussion of this point.)

52 Earlier versions of this paper were presented at: the Association for Legal and Social Philosophy (Queen's University, UK, 2012); the Centre for Ethics (University of Toronto, Canada, 2015); the International Conference on Affective, Moral, and Civic Education (Université de Montréal, Canada, 2015); and the Manchester Centre for Political Theory (MANCEPT) workshop on "Liberal Neutrality and Oppression" (Manchester University, UK, 2017). My thanks to the participants at those presentations and workshops for their questions and comments. I especially would like to thank: Michael Barnes, Simone Chambers, Jürgen De Wispelaere, Elizabeth Edenberg, Andrew FranklinHall, Carol Hay, Joseph Heath, Waheed Hussain, Colin MacLeod, Emily McGill, Lars Moen, and Lori Watson.

\section{References}

Anderson, Elizabeth. 2017. Private Government. Princeton: Princeton University Press.

Berlin, Isaiah. 1969a. "Introduction." In Four Essays on Liberty, xxxvii-lxiii. Oxford: Oxford University Press.

Berlin, Isaiah. 1969b. "Two Concepts of Liberty." In Four Essays on Liberty, 118-72. Oxford: Oxford University Press.

Darwall, Stephen. 1995. "Two Kinds of Respect." In Dignity, Character, and Self-Respect, edited by Robin S. Dillon, 181-97. New York: Routledge.

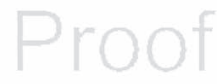




\section{Blain Neufeld}

Darwall, Stephen. 2006. The Second-Person Standpoint. Cambridge: Harvard University Press.

Davis, Gordon F., and Blain Neufeld. 2007. "Political Liberalism, Civic Education, and Educational Choice." Social Theory and Practice 43(1): 47-74.

De Francisco, Andrés. 2006. "A Republican Interpretation of the Late Rawls." The Journal of Political Philosophy 14: 270-88.

Ferejohn, John. 2001. "Pettit's Republic." The Monist 84(1): 77-97.

Gutmann, Amy. 1995. "Civic Education and Social Diversity." Ethics 105(3): $557-79$.

Hartley, Christie, and Lori Watson. 2010. "Is a Feminist Political Liberalism Possible?" Journal of Ethics and Social Philosophy 5(1): 1-21. www.jesp.org.

Kant, Immanuel. 1998. Groundwork of the Metaphysics of Morals. Edited and Translated by Mary Gregor. Cambridge: Cambridge University Press.

Laden, Anthony S. 2006. "Republican Moments in Political Liberalism." Revue Internationale de Philosophie 237: 341-67.

Levine, Peter, and Kei Kawashima-Ginsberg. 2017. The Republic is (Still) at Risk-and Civics is Part of the Solution. Medford, MA: Jonathan M. Tisch College of Civic Life, Tufts University.

List, Christian, and Laura Valentini. 2016. "Freedom as Independence." Ethics 126: 1043-74.

Lovett, Frank. 2012. "What Counts as Arbitrary Power?" Journal of Political Power 5(1): 137-52.

Lovett, Frank. 2014. "Republicanism." Stanford Encyclopedia of Philosophy (last edited 15 April 2014). https://plato.stanford.edu/entries/republicanism/.

MacCallum, Jr., Gerald C. 1967. "Negative and Positive Freedom.” Philosophical Review 76(3): 312-34.

Neufeld, Blain. 2005. "Civic Respect, Political Liberalism, and Non-Liberal Societies." Politics, Philosophy \& Economics 4(3): 275-99.

Neufeld, Blain. 2009. "Coercion, the Basic Structure, and the Family." Journal of Social Philosophy 40(1): 37-54.

Neufeld, Blain. 2013. "Political Liberalism and Citizenship Education." Philosophy Compass 8(9): 781-97.

Neufeld, Blain. 2017. "Why Public Reasoning Involves Ideal Theorizing." In Political Utopias: Contemporary Debates, edited by Michael Weber and Kevin Vallier, 73-93. Oxford: Oxford University Press.

Neufeld, Blain, and Chad Van Schoelandt. 2014. "Political Liberalism, Ethos Justice, and Gender Equality." Law and Philosophy 33(1): 75-104.

Okin, Susan M. 1994. "Political Liberalism, Justice, and Gender." Ethics 105: 23-43.

Okin, Susan M. 2002. “'Mistresses of their Own Destiny': Group Rights, Gender, and Realistic Rights of Exit." Ethics 112: 205-30.

Okin, Susan M. 2005. "'Forty Acres and a Mule' for Women: Rawls and Feminism." Politics, Philosophy \& Economics 4: 233-48.

Pettit, Philip. 1996. "Freedom as Anti-Power." Ethics 106: 576-604.

Pettit, Philip. 1997. Republicanism: A Theory of Freedom and Government. Oxford: Oxford University Press.

Pettit, Philip. 2006. "Rawls's Peoples." In Rawls's Law of Peoples: A Realistic Utopia?, edited by Rex Martin and David A. Reidy, 38-55. Oxford: Blackwell Publishing. 
Pettit, Philip. 2011. "The Instability of Freedom as Non-Interference: The Case of Isaiah Berlin." Ethics 121: 693-716.

Pettit, Philip. 2012. On the People's Terms: A Republican Theory and Model of Democracy. Cambridge: Cambridge University Press.

Rawls, John. 1999. A Theory of Justice: Revised Edition. Cambridge: Harvard University Press.

Rawls, John. 2001. Justice as Fairness: A Restatement. Cambridge: Harvard University Press.

Rawls, John. 2005. Political Liberalism: Expanded Edition. New York: Columbia University Press.

Simpson, Thomas W. 2017. "The Impossibility of Republican Freedom.” Philosophy \& Public Affairs 45(1): 27-53.

Talisse, Robert B. 2014. "Impunity and Domination: A Puzzle for Republicanism." European Journal of Political Theory 13(2): 121-31.

Vallier, Kevin. 2012. "Liberalism, Religion, and Integrity." Australasian Journal of Philosophy 90: 149-65.

Watson, Lori, and Christie Hartley. 2018. Equal Citizenship and Public Reason: A Feminist Political Liberalism. New York: Oxford University Press.

Wolterstorff, Nicholas. 1997. "Why We Should Reject What Liberalism Tells Us About Speaking and Acting in Public for Religious Reasons." In Religion and Contemporary Liberalism, edited by Paul Weithman, 162-81. Notre Dame: University of Notre Dame Press.

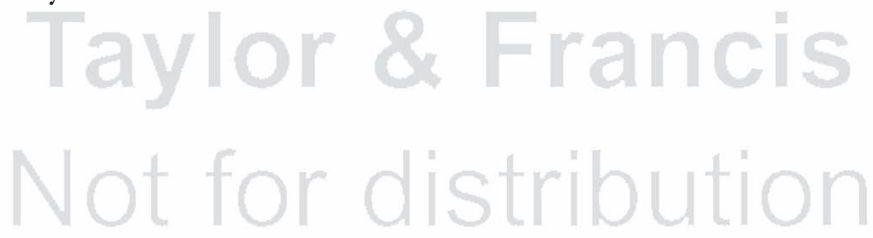

